\title{
Effects of increased self-regulated learning opportunities on student teachers' metacognitive and motivational development.
}

Citation for published version (APA):

Vrieling, E., Bastiaens, T., \& Stijnen, S. (2012). Effects of increased self-regulated learning opportunities on student teachers' metacognitive and motivational development. International Journal of Educational Research, 53(2012), 251-263. https://doi.org/10.1016/j.jjer.2012.03.014

DOI:

10.1016/j.jijer.2012.03.014

Document status and date:

Published: 01/01/2012

Document Version:

Peer reviewed version

Please check the document version of this publication:

- A submitted manuscript is the version of the article upon submission and before peer-review. There can be important differences between the submitted version and the official published version of record. People interested in the research are advised to contact the author for the final version of the publication, or visit the DOI to the publisher's website.

- The final author version and the galley proof are versions of the publication after peer review.

- The final published version features the final layout of the paper including the volume, issue and page numbers.

Link to publication

\section{General rights}

Copyright and moral rights for the publications made accessible in the public portal are retained by the authors and/or other copyright owners and it is a condition of accessing publications that users recognise and abide by the legal requirements associated with these rights.

- Users may download and print one copy of any publication from the public portal for the purpose of private study or research.

- You may not further distribute the material or use it for any profit-making activity or commercial gain

- You may freely distribute the URL identifying the publication in the public portal.

If the publication is distributed under the terms of Article $25 \mathrm{fa}$ of the Dutch Copyright Act, indicated by the "Taverne" license above, please follow below link for the End User Agreement:

https://www.ou.nl/taverne-agreement

Take down policy

If you believe that this document breaches copyright please contact us at:

pure-support@ou.nl

providing details and we will investigate your claim.

Downloaded from https://research.ou.nl/ on date: 26 Apr. 2023 


\title{
Effects of increased self-regulated learning opportunities on student teachers' metacognitive and motivational development
}

\author{
E.M. Vrieling*ab, T.J. Bastiaens ${ }^{\mathrm{bc}}$, S. Stijnen $^{\mathrm{b}}$ \\ ${ }^{a}$ IJsselgroep, Iselinge Hogeschool, Doetinchem, The Netherlands; ${ }^{b}$ RdMC, Open University, \\ Heerlen, the Netherlands; ${ }^{c}$ Institut für Bildungswissenschaft und Medienforschung, \\ Fernuniversität in Hagen, Hagen, Germany \\ *Corresponding author. PO Box 277, 7000 AG, Doetinchem, the Netherlands. E-Mail address: \\ emmy.vrieling@ijsselgroep.nl
}

Pre-print; published in International Journal of Educational Research, 53, 251-263.

This intervention study focused on the relationships between student teachers' self-regulated learning (SRL) opportunities, their use of metacognitive learning strategies and their motivation for learning. Results indicate that student teachers' use of metacognitive learning strategies increases significantly in learning environments with increased SRL opportunities. In opposite to these findings, no significant difference was shown between student teachers' motivation for learning before and after the research period. However, student teachers' expectancy, a component within the motivational construct, did increase significantly in the research period. Finally, minor significant positive correlations were found between the metacognitive and motivational constructs measured. In general, the level of SRL opportunities turns out to be a moderate predictor of student teachers' use of metacognitive learning strategies and motivation for learning, both important constructs for their academic career.

Keywords: higher education, metacognition, motivation, pre service teacher learning, self-regulated learning 


\section{Introduction}

This article describes an intervention study that focused on the relationships between primary student teachers' (i.e., prospective primary teachers) self-regulated learning (SRL) opportunities, their use of metacognitive learning strategies and their motivation for learning, both important constructs for student teachers' academic success.

\subsection{Primary teacher education and SRL}

Most teacher education programs have traditionally been based on teaching subject knowledge and training teaching skills (Kremer-Hayon \& Tillema, 1999). However, researchers and practitioners in teacher education are increasingly confronted with the lack of transfer from theory to practice. In other words, primary student teachers are often not able to translate the provided knowledge and skills throughout their initial training in actual teaching practices in the schools (Korthagen, Klaassen, \& Russell, 2000).

In response to this problem, primary teacher educators (i.e., teachers of prospective primary teachers) nowadays are striving to increase student teachers' SRL opportunities in educational pre-service programs (Lunenberg \& Korthagen, 2003). In a society that requires lifelong learning, the ability to steer one's own learning is becoming more and more important to be successful in academic as well as in non-academic contexts (Kremer-Hayon \& Tillema, 1999). In general, SRL is defined as 'an active, constructive process whereby learners set goals for their learning and then attempt to monitor, regulate, and control their cognitions, motivation, and behavior, guided and constrained by their goals and the contextual features in the environment (Pintrich, 2000, p. 453). Students in higher education who can better regulate their academic functioning are more successful in learning, problem solving, transfer and academic achievement in general (Nota, Soresi, \& Zimmerman, 2004; Sundre \& Kitsantas, 2004; Valle et al., 2003; VanderStoep, Pintrich, \& Fagerlin, 1996). This may also be the case with students in teacher education.

As a consequence, primary teacher educators are increasingly urged to renew their teaching concepts to encourage student teachers to demonstrate a high degree of SRL by learning as professionals, constructing their practical knowledge, developing an attitude of reflective inquiry and experimenting with ideas and teaching skills (Kremer-Hayon \& Tillema, 1999). To support teacher educators in this SRL implementation process, Vrieling, Bastiaens, and Stijnen (2010), formulated seven process-oriented design principles, summarized in an SRL model for primary teacher education. The recommendations of this SRL model point out the importance: (1) to create a sufficient knowledge base for student teachers in the domain (subject area); (2) to facilitate this knowledge building by integrating the necessary metacognitive skills and content matter during teaching; (3) to model these metacognitive skills by using four regulatory skill levels, namely observation, emulation, self-control and self-regulation; (4) to gradually develop from teacher control to student control over learning processes (scaffolding); (5) to be aware of the conditional factors that can hinder or foster SRL development; (6) to engage student teachers in collaborative learning environments; and (7) to pay attention to the relevant SRL aspects of the learning task (goal setting, prior knowledge activation, metacognitive knowledge activation, metacognitive awareness and monitoring of cognition, judgments, attributions, task value activation and time management). The model was applied in primary teacher education and first findings demonstrate that the model provides more insight for teacher educators into relevant SRL aspects (Vrieling et al., 2011a). 


\subsection{Relevant SRL concepts for student teachers' academic success}

Recent models of SRL include motivational beliefs or attitudes together with cognitive and metacognitive learning strategies (Wolters, 2003). Pintrich (2000, 2004), for example, demonstrates motivation as a key factor of SRL that is infused throughout all four phases: 1) forethought, planning, and activation, 2) monitoring, 3) control, 4) reaction and reflection. Motivational variables interact with cognitive, behavioral, and contextual factors to affect SRL and conceptual change. For example, self-regulated learners show more self-efficacy for learning than students with poorer SRL skills; the former believe that they can use their SRL skills to help them learn (Zimmerman, 2000). In such socio-cognitive approaches of SRL, the cognitions, motivations and learning of individuals cannot be comprehended unless social and cultural context, such as support from teachers and feedback from peers, are taken into consideration (Järvelä, Järvenoja, \& Veermans, 2008).

Motivation can be seen as either a product or a process (Wolters, 2003). When viewed as a product, students have a level of motivation that they experience and that influences their choice, effort and persistence regarding a particular activity. When viewed as a process, motivation refers not just to an end state but also the means through which that state is determined. In other words, motivational tendencies change during learning in classroom practice (Järvelä et al., 2008) and students can learn to regulate their motivational state (Wolters, 2003).

For example, academic goals are regarded as important variables in current motivational research because goals serve as self-defining reference points that determine the further processes of SRL, such as planning, executing and monitoring (Schunk \& Ertmer, 2000; Zimmerman, 1999). Goals are cognitive representations of the various aims that students can adopt in different achievement situations (Valle et al., 2003).

In the literature on goal orientations, a general distinction is drawn between mastery and performance goals (Elliot \& Mc Gregor, 2001; Schunk, 2005). Mastery goals reflect a focus on the acquisition of knowledge, skill, and competence relative to one's prior performance; performance goals involve a striving to demonstrate competence by outperforming peers. In line with Pintrich (2000), Elliot and Mc Gregor (2001) adopted a multiple goals perspective on motivation by crossing this mastery-performance dimension with an approach-avoid dimension according to whether students were attempting to approach or avoid the goals. Mastery-approach goals concern working on tasks to develop skills. Mastery-avoid goals might involve avoiding the possibility of not meeting high standards. Performance-approach goals include a focus on outperforming others. Performance-avoid goals entail a concern with avoiding the demonstration of low ability. Research has identified self-regulatory benefits of mastery-approach goals (Schunk, 2005) such as better cognitive monitoring and use of learning strategies while engaged in academic learning.

In general, students who display more adaptive SRL strategies demonstrate better learning and higher motivation for learning (Schunk, 2005), finally resulting in higher academic achievement (e.g. Bruinsma, 2004; Pintrich, 2000, 2004). When it comes to primary teacher education, Vrieling et al. (2011a) also showed significant positive relations between SRL opportunities and motivation for learning to a strong extent. Although the level of SRL opportunities was a significant positive predictor of the motivational score, student teachers' level of motivation did not increase significantly in the research period (one semester). By contrast was shown that the expectancy component within the motivational scale did increase significantly for 2 of the 3 teacher educators after the SRL treatments. The expectancy scale includes control belief and selfefficacy for learning and performance, e.g. 'I think that I will get good grades for this course'. 
At the same time, self-regulated learners are able to apply a large arsenal of cognitive learning strategies in academic tasks. Pintrich (2000, 2004), for example, distinguishes rehearsal, organization, and elaboration as cognitive learning strategies in his SRL model. Moreover, when it comes to the metacognitive concept in SRL, its role is generally acknowledged as critical in constructivist views of learning (e.g. Butler, 2002; Efklides, 2006; Zimmerman \& Schunk, 2001). In the context of primary teacher education, the findings of a pilot study of Vrieling et al. (2011a) also demonstrated that student teachers' use of metacognitive skills increased significantly for 2 of the 3 participating teacher educators in learning environments with increased SRL opportunities. Some theorists view SRL as a subordinate component of metacognition whereas others regard SRL as a super-ordinate to metacognition (Veenman, Van Hout-Wolters, \& Afflerbach, 2006). In line with Muis and Franco (2010), the present study explores metacogniton from a regulation of cognition perspective, situated as a subordinate to SRL.

Metacognition can be defined as the knowledge about and the regulation of one's cognitive activities in learning processes (Veenman, et al., 2006). It represents 'the awareness learners have about their general academic strengths and weaknesses, cognitive resources they can apply to meet the demands of particular tasks, and their knowledge about how to regulate engagements in tasks to optimize learning processes and outcomes' (Winne \& Perry, 2000, p. 533). Such active and self-regulated strategy use is found positively related to achievement (e.g. Pintrich \& De Groot, 1990; Zimmerman \& Pons, 1988). The use of metacognitive skills enables students to become aware of and monitor their progress towards their goals. In this way, they can improve their learning and comprehension. As a result, students can realize any adaptive changes in their learning (Vermunt \& Verloop, 1999).

Many researchers indicate that student motivation and use of learning strategies are related (Bruinsma, 2004; Eccles \& Wigfield, 2002; Pintrich, 2000, 2004; Pintrich \& De Groot, 1990). In the case of primary teacher education, Vrieling et al. (2011a) also found significant positive relations between student teachers' study process (one of the two sub scales within metacognition) and motivation for learning. In other words, more motivated students are more likely to use more cognitive and metacognitive strategies and are more effective in their effort regulation. Berger and Karabenick (2011) also found evidence for the relatedness between student' motivation and use of learning strategies. More specific, their research shows no reciprocal, but unidirectional effects between the two constructs: motivation predicts the use of learning strategies, but the use of learning strategies does not predict motivation.

\subsection{Problem definition}

Although primary student teachers are increasingly required to self-regulate their' learning, the consequences of these increased SRL opportunities for student teachers' academic success have not been measured on a large scale so far. Therefore, the present study explored dynamics of primary student teachers' use of metacognitive learning strategies and motivation for learning in learning environments with increased SRL opportunities. As stated earlier, these two concepts are relevant in determining academic performance.

The socio-cognitive models of SRL, as described in section 1.2, were the starting points to focus on in the present study. Both the individual and the social context were targets for data collection and analyses. The measurement of SRL, motivation and metacognition was considered from a process-oriented approach (Järvelä et al., 2008) and therefore observed as an integral part of the overall process during the course of all learning activities. 
Based on theory and the results of the pilot study by Vrieling et al. (2011a), the following hypotheses were investigated in the present study:

- Student teachers' use of metacognitive learning strategies increases significantly during one semester in learning environments with increased SRL opportunities.

- Student teachers' motivation for learning increases significantly during one semester in learning environments with increased SRL opportunities.

- Student teachers' motivation for learning is significantly related to student teachers' use of metacognitive learning strategies.

This article continues with a description of the methods used, containing an explanation of the participants, the research instruments, the procedure, data collection and analysis. Then, the results of the study are outlined and conclusions for primary teacher education are discussed. Finally, the limitations of the study and indications for future research are formulated.

\section{Method}

\subsection{Participants}

From January 2010 until June 2010, the exploration of the effects of student teachers' increased SRL opportunities on student teachers' use of metacognitive learning strategies and their motivation for learning was conducted with 11 teacher educators and 257 (36 Males and 221 females) second-year (mainly 18-20 year old; mean age 18,94 year) student teachers of 17 student groups in 5 primary teacher education colleges in the Netherlands. Two of the 5 participating teacher education institutes were independent institutes. The other 3 institutes were part of larger higher education institutes. All institutes were located in the eastern, southern and western parts of the Netherlands.

The research was carried out in educational theory courses containing lectures, lessons and moments of guidance. Only teacher educators with a minimum of 10 lessons in the research period and teaching fulltime regular student teachers were allowed to participate. All participating teacher educators volunteered to cooperate. The 17 groups of student teachers were relatively similar in terms of their age, gender and level of education. Student teachers' former level of education comprised lower general, followed by senior secondary education (low level, $\mathrm{N}=32$ ), higher general secondary education (middle level, $\mathrm{N}=219$ ), and pre-university education (high level, $\mathrm{N}=6$ ).

\subsection{Instruments}

In studies of Vrieling et al. (2011a, b), two instruments for primary teacher education were developed: (1) the 'SRL Opportunities Questionnaire' (SRLOQ) that enables teacher educators to measure the degree of SRL opportunities they provide to student teachers, and (2) the 'Motivation and Metacognition Questionnaire' (MMQ) that measures the level of student teachers' motivation for learning as well as their use of metacognitive learning strategies. The development of the SRLOQ was based on a theoretical review (Vrieling et al., 2010) that resulted in seven process-oriented design principles, representing relevant SRL categories for primary teacher education. These categories were divided by Vrieling et al. (2011b) into specific aspects and operationalized in potentially relevant items of the questionnaire. Then, these items were screened for their relevance in primary teacher education and their possible overlap and gaps with other items, leading to a final selection of items, in analogous versions for student teachers and teacher educators. 
The SRLOQ was completed by 62 first- and second-year student teachers and 29 teacher educators and categorizes items into 5 different SRL scales: planning (Cronbach's $\alpha=.84$; sample item: 'The teacher expects me to make a time plan for working on my learning goals'), monitoring of the learning process (Cronbach's $\alpha=.81$; sample item: 'The teacher expects me to point out in which areas I need feedback'), zone of proximal development (Cronbach's $\alpha=.84$; sample item: 'The manual describes in what way I can prepare myself for the lessons'), coaching/judging (Cronbach's $\alpha=.86$; sample item: 'The grading of the assignments by the teacher is based on previously formulated criteria') and collaboration (Cronbach's $\alpha=.61$; sample item: 'During collaboration, the teacher pays attention to specific collaboration skills such as dividing tasks and reporting to each other'). The SRLOQ consists of 56 items scored on a five-point Likert scale. Student teachers have to indicate to what extent each item is true for them.

For the development of the MMQ, the 'Motivated Strategies for learning Questionnaire' (MSLQ, Pintrich et al., 1991) was used as a starting point for three reasons: (1) it distinguishes a motivational and a metacognitive part; (2) it focuses on the course level of college students; and (3) it has been applied and validated at different educational levels, including higher education. The MSLQ was translated into Dutch and validated by Blom and Severiens (Blom \& Severiens, 2008; Blom, Severiens, Broekkamp \& Hoek, 2005) in Dutch schools of general secondary higher education and pre-university education.

The translated MSLQ by Blom and Severiens and the original MSLQ by Pintrich et al. were analyzed on differences by Vrieling et al. (2011a). In the metacognition part (the items regarding 'metacognitive self-regulation'), it was noticed that both versions of the MSLQ only measure for the study process. As a consequence, the distinction between study process, study results and study content, as described in the 'Inventory of Learning Styles' (ILS, Vermunt \& Van Rijswijk, 1987), was retained in the MMQ to complete the metacognitive construct. Finally, scale analysis led to combining study process and study results into one final study process construct with sufficient value of Cronbach's Alpha $(0,76)$.

Furthermore, in the motivation part of the original and translated MSLQ was noted that the MSLQ does not distinguish between approach and avoidance goals orientation, but only represents a mastery approach orientation (intrinsic goal orientation) and a performance approach orientation (extrinsic goal orientations). As a result, the mastery-avoidance and performance-avoidance items, as proposed and tested by Elliot and Mc Gregor (2001), were analyzed. Their $2 \times 2$ achievement goal framework was tested in 3 studies, supporting the independence of the 4 achievement goal constructs. As a result, the mastery-avoidance and performance-avoidance items of the framework were added to the MMQ to complete and improve the motivational construct.

For the metacognition part, two scales were distinguished: study process (Cronbach's $\alpha=.76$; sample item: 'When I study for this course, I reflect on questions to keep my mind on the job') and study content (Cronbach's $\alpha=.82$; sample item: 'Besides the content of the examination, I also study extra literature related to the course'). The motivation section comprises seven scales: intrinsic goal orientation (Cronbach's $\alpha=.73$; sample item: 'During this course, I prefer challenging subject material so I can learn new things'), extrinsic goal orientation (Cronbach's $\alpha=.77$; sample item: 'I want to do better than the average student'), intrinsic goal avoidance (Cronbach's $\alpha=.81$; sample item: 'I worry about not getting the full benefit out of this course'), extrinsic goal avoidance (Cronbach's $\alpha=.72$; sample item: 'I only want to avoid doing poorly for this course', task value (Cronbach's $\alpha=.74$; sample item: 'I think the course material in this class 
is useful for me to learn'), expectancy (Cronbach's $\alpha=.90$; sample item: 'I think that I will get good grades for this course ') and test anxiety (Cronbach's $\alpha=.89$; sample item: 'I suffer from nerves when I take an exam'). The MMQ was completed by 67 student teachers and contains 51 items scored on a five-point Likert scale. Student teachers have to indicate to what extent each item is true for them.

In general, the values of Cronbach's Alpha's for the different scales of both questionnaires imply reasonable reliability and homogeneity of items within the scales. Consequently, both instruments were used in the present study.

\subsection{Procedure}

In order to answer the research questions of the present study, an intervention study was conducted using a mixed methods pre- and post-test design. No control groups were used because of the difficulty for teacher educators to differentiate in the level of provided SRL opportunities between their student groups. Table 1 visualizes the research design of the intervention study. Student teachers' SRL opportunities, motivation for learning and use of metacognitive learning strategies were measured with respectively the SRLOQ and the MMQ. Teacher educators and student teachers were qualitatively tracked by tutorial conversations (teacher educators) and semi-structured interviews (teacher educators and student teachers). In this one-group pre- and post-test design, the pre-test (completing both questionnaires) was performed at the end of the third lesson (week 4). At that time, teacher educators and student teachers were expected to be unaware of the increased SRL opportunities that would be applied in the intervention-period and student teachers were expected to be able to indicate their starting level of SRL opportunities. By monitoring both teacher educators and student teachers on SRL opportunities rather than teacher educators alone, the statements of both groups could be compared to obtain better interpretable data. After the pre-test, two kinds of treatments were carried out with teacher educators aimed at increasing student teachers' SRL opportunities: (1) training courses after lesson 3 (week 5) and (2) individual tutorial conversations after lesson 4 (week 6). The tutorial conversations were based on analyses of the pre-test.

The intermediate-test (completing the SRLOQ) was performed at the end of the sixth lesson (week 10). Based on analyses of the intermediate-test, tutorial conversations were carried out again after lesson 6 (week 11) aimed at a further increase of student teachers' SRL opportunities. At the end of the last lesson (week 18), the post-test (completing both questionnaires) was conducted. Within five days after the post-test (end of week 18), all teacher educators and a sample of student teachers were interviewed in depth.

Table 1. Research design intervention study

\begin{tabular}{|c|c|c|c|c|c|c|c|c|c|c|c|c|c|c|c|c|c|c|}
\hline Weeks & $\overline{1}$ & 2 & 3 & 4 & 5 & 6 & 7 & 8 & 9 & 10 & 11 & 12 & 13 & 14 & 15 & 16 & 17 & 18 \\
\hline Lessons & $\mathrm{X}$ & $\mathrm{x}$ & & $\mathrm{x}$ & & $\mathrm{x}$ & $\mathrm{x}$ & & & $\mathrm{x}$ & & $\mathrm{X}$ & & & & $\mathrm{x}$ & $\mathrm{x}$ & $\mathrm{x}$ \\
\hline SRLOQ (TEs and STs) & & & & $\mathrm{x}$ & & & & & & $\mathrm{x}$ & & & & & & & & $\mathrm{x}$ \\
\hline MMQ (STs) & & & & $\mathrm{x}$ & & & & & & & & & & & & & & $\mathrm{x}$ \\
\hline Course (TEs) & & & & & $\mathrm{x}$ & & & & & & & & & & & & & \\
\hline Conversations (TEs) & & & & & & $\mathrm{x}$ & & & & & $\mathrm{x}$ & & & & & & & \\
\hline Interviews (TEs and STs) & & & & & & & & & & & & & & & & & & $\mathrm{x}$ \\
\hline
\end{tabular}

\subsection{Data collection and analysis}

Student teachers' motivation for learning and their use of metacognitive skills were assessed using both quantitative and qualitative methods. Quantitative analyses (correlation analyses, 
independent-samples t-tests, paired-samples t-tests and regression analyses) were based on the data of the pre- and the post-test for all participating teacher educators. The data of the intermediate-test (completing the SRLOQ) were not used for the quantitative analyses because the research period only lasted 10 weeks at that time, a too short period to find preliminary results. However, the gathered data of the intermediate-test did provide the necessary input for the second cycle of consulting conversations with primary teacher educators.

The degrees of freedom in the independent-samples t-tests varied because the participating student teachers were allowed to skip questions of the questionnaires. No analyses of variance could be applied to show influences of age, gender or level of former education on student teachers' use of metacognitive learning strategies and motivation for learning mainly because of the small samples of male student teachers $(\mathrm{N}=36)$, student teachers with a low $(\mathrm{N}=32)$ or high level of education $(\mathrm{N}=6)$ and the small age variation (18-20 years).

Qualitative analyses were based on the data of semi-structured interviews. The first cycle of the tutorial conversations with teacher educators was grounded on both teacher educators' SRL planning and analyses of the pre-test. The SRLOQ scales were the leading themes of the conversations. The concept planning of the teacher educators (a result from the SRL course) and analyses of the measured SRL degree as viewed by teacher educators and student teachers, were compared. This comparison resulted in an adjusted planning for SRL implementation in classroom practice for teacher educators.

Based on analyses of the intermediate-test, the second cycle of tutorial conversations resulted in an adjusted SRL planning for teacher educators, aiming at a further increase of student teachers' SRL opportunities in the learning program.

In the post-test, all teacher educators and a sample of student teachers ( 2 per teacher educator) were questioned in semi-structured interviews about their experiences with and perceptions of student teachers' increased SRL opportunities in educational programs. Semistructured interviews were considered to be most suitable since developments with respect to SRL in primary teacher education are rather new and complex and not suitable to be asked about in questionnaires only. The scales of the SRLOQ and the MMQ were used as starting points for the topics of the interviews. The interviews took approximately 45 minutes.

The semi-structured interviews with the student teachers (see Appendix A) were focused on the way student teachers had experienced the increased SRL opportunities and how these changed learning conditions influenced their motivation for learning and use of metacognitive learning strategies during the research period. Student teachers were asked what stroke them during the research period concerning teacher educators' teaching behavior and how they reacted on this changed behavior. For each example of teacher educators' behavior, student teachers were asked to explain how this teaching behavior influenced their motivation for learning and their use of metacognitive learning strategies. In the end, student teachers were asked to provide compliments and advices for their teachers.

The semi-structured interviews with the teacher educators (see Appendix A) were based on both teacher educators' SRL planning and analyses of the post-test. The SRL planning of the teacher educators and analyses of the measured SRL degree as viewed by teacher educators and student teachers were compared. Teacher educators were asked for the reason of the choices concerning the provided SRL opportunities, if they would make the same choices if they had the chance to repeat the intervention trajectory, what changes were observed in student teachers' motivation for learning and their use of metacognitive learning strategies and to provide examples of these changes in student teachers' behavior. 
In line with Miles and Huberman (1994), the collected data and the used instruments (questionnaires, tutorial conversations, semi-structured interviews) were analyzed and related to each other by triangulation to enhance the internal validity of the results. First, all quantitative and qualitative findings were structured in a matrix containing the scales of the SRLOQ (planning, monitoring of the learning process, zone of proximal development, coaching/judging, collaboration) and the MMQ (metacognition: study process, study content and motivation: intrinsic goal orientation, extrinsic goal orientation, intrinsic goal avoidance, extrinsic goal avoidance, task value, expectancy and test anxiety) and, per scale, all different sources of data collection (analyses pre-, intermediate- and post-test as viewed by teacher educators and student teachers, consulting conversations, semi-structured interviews). Second, the content of each category was examined and described for each teacher educator separately. Third, similarities and differences in teacher educators' and student teachers' view of SRL opportunities and the consequences for motivation and metacognition were analyzed. For this purpose, patterns in teacher educators' and student teachers' knowledge and beliefs were identified and described. These "patterns" refer to groups of associated statements that give insight into the similarities and differences in the knowledge and beliefs of the teacher educators and student teachers. Finally, the results of the analysis of the data provided by the different instruments were synthesized in order to gain a deeper level of insight into teacher educators' and student teachers' practical knowledge.

\section{Results}

In this section, the three hypotheses of the study are addressed separately. First, the results of quantitative analyses are presented, followed by the qualitative findings.

Student teachers' use of metacognitive learning strategies increases significantly during one semester in learning environments with increased SRL opportunities.

The relationship between student teachers' SRL opportunities and their use of metacognitive learning strategies was firstly studied by means of correlation analyses (Table 2).

Table 2: Pearson correlation coefficients between SRL opportunities, metacognition and motivation

\begin{tabular}{|c|c|c|c|}
\hline Scale & Condition & SRL opportunities & Motivation \\
\hline \multirow[t]{2}{*}{ Metacognition } & Pre-test & $0,544^{*}$ & $0,212 *$ \\
\hline & Post-test & $0,542 *$ & $0,338 *$ \\
\hline \multirow[t]{2}{*}{ Study Process } & Pre-test & $0,545^{*}$ & \\
\hline & Post-test & $0,531 *$ & \\
\hline \multirow[t]{2}{*}{ Study Content } & Pre-test & $0,434 *$ & \\
\hline & Post-test & $0,385^{*}$ & \\
\hline \multirow[t]{2}{*}{ Motivation } & Pre-test & $0,210 * *$ & \\
\hline & Post-test & $0,500^{*}$ & \\
\hline \multirow{2}{*}{ Intrinsic goal orientation } & Pre-test & $0,230 *$ & \\
\hline & Post-test & $0,557 *$ & \\
\hline \multirow[t]{2}{*}{ Intrinsic goal avoidance } & Pre-test & $-0,242 *$ & \\
\hline & Post-test & $-0,140 *$ & \\
\hline \multirow[t]{2}{*}{ Extrinsic goal orientation } & Pre-test & $0,534^{*}$ & \\
\hline & Post-test & $0.589 *$ & \\
\hline \multirow[t]{2}{*}{ Extrinsic goal avoidance } & Pre-test & $-0,391 *$ & \\
\hline & Post-test & $-0,219 *$ & \\
\hline \multirow[t]{2}{*}{ Task value } & Pre-test & $0.505^{*}$ & \\
\hline & Post-test & $0,648 *$ & \\
\hline
\end{tabular}




\begin{tabular}{lll}
\hline Expectancy & Pre-test & $0,275^{*}$ \\
& Post-test & $0,582^{*}$ \\
Test anxiety & Pre-test & $-0,363^{*}$ \\
& Post-test & $-0,126^{*}$ \\
\hline
\end{tabular}

* significance: $\mathrm{p}<0.01$, one-tailed

$* *$ significance: $\mathrm{p}<0.05$, one-tailed

Significant correlations at the 0,01 significance level were found between student teachers' SRL opportunities and their use of metacognitive learning strategies both before $(r=0,544)$ and after $(r=0,542)$ increasing the SRL opportunities. These results indicate a moderate positive relationship between the provided SRL opportunities in educational pre-service programs and student teachers' use of metacognitive learning strategies. The same holds for the separate constructs within metacognition: 'study process' ( $r=0,545$ in the pre-test and 0,531 in the posttest) and 'study content' ( $r=0,434$ in the pre-test and 0,385 in the post-test).

In order to analyze the dynamics in student teachers' SRL opportunities and their use of metacognitive learning strategies, independent-samples t-tests were applied secondly. Since the pre- and post-test samples of the present study are not independent, the independent-samples ttests were only applied to estimate the significance of the increase of student teachers' use of metacognitive learning strategies. Independent-samples t-tests assume the covariance between the two samples to be zero, which is not the case between our pre- and post-test samples. As a consequence, the estimated significance of the metacognitive increase is too low and therefore presents minimum values. Table 3 represents student teachers' use of metacognitive learning strategies before (pre-test) and after (post-test) increasing student teachers' SRL opportunities in the educational pre-service program.

The results of the independent-samples t-tests were confirmed by applying paired-samples ttests. Because the quantitative measurements of the pre- and post-test were conducted anonymously, analyses were performed on the level of the student groups. Table 4 represents student teachers' use of metacognitive skills for learning before (pre-test) and after (post-test) increasing student teachers' SRL opportunities for all participating 17 groups.

Table 3: Results of the independent-samples t-tests for metacognition and motivation

\begin{tabular}{|c|c|c|c|c|c|c|c|c|c|c|}
\hline Scale & Conditions & $\mathrm{M}$ & $\mathrm{SD}$ & $\mathrm{K}-\mathrm{S}$ & $\bar{p}$ & $\bar{F}$ & $p$ & $t$ & $d f$ & $p$ \\
\hline \multirow[t]{2}{*}{ Metacognition } & Pre test & 51,88 & 10,47 & 1,145 & 0,145 & 4,211 & 0,041 & 4,940 & 354 & $0,000^{*}$ \\
\hline & Post test & 57,02 & 9,16 & 0,730 & 0,661 & & & & & \\
\hline \multirow[t]{2}{*}{ Study process } & Pre test & 42,16 & 8,22 & 1,158 & 0,137 & 4,332 & 0,038 & 4,017 & 357 & $0,000^{*}$ \\
\hline & Post test & 45,43 & 7,18 & 0,744 & 0,638 & & & & & \\
\hline \multirow[t]{2}{*}{ Study content } & Pre test & 9,85 & 3,10 & 1,088 & 0,187 & 0,487 & 0,486 & 5,171 & 371 & $0,000^{*}$ \\
\hline & Post test & 11,49 & 3,02 & 1,633 & 0,010 & & & & & \\
\hline \multirow[t]{2}{*}{ Motivation } & Pre test & 113,05 & 12,22 & 0,759 & 0,612 & 0,919 & 0,339 & 0,659 & 336 & 0,255 \\
\hline & Post test & 112,14 & 13,00 & 1,148 & 0,143 & & & & & \\
\hline \multirow[t]{2}{*}{ Expectancy } & Pre test & 27,11 & 4,46 & 0,924 & 0,360 & 2,317 & 0,129 & 2,069 & 353 & $0,020 * *$ \\
\hline & Post test & 28,14 & 4,89 & 0,744 & 0,588 & & & & & \\
\hline
\end{tabular}

* significance: $\mathrm{p}<0.01$, one-tailed

** significance: $\mathrm{p}<0.05$, one-tailed

Table 4: Results of the paired-samples t-tests for metacognition and motivation

\begin{tabular}{lllllllll}
\hline Scale & Conditions & M & SD & K-S & $p$ & $t$ & $d f$ & $p$ \\
\hline Metacognition & Pre-test & 52,03 & 4,87 & 0,547 & 0,925 & 8,418 & 16 & $0,000^{*}$ \\
\hline
\end{tabular}




\begin{tabular}{cllllllll}
\hline \multirow{2}{*}{ Study process } & Post-test & 57,01 & 4,19 & 0,851 & 0,463 & & & \\
& Pre-test & 41,97 & 3,91 & 0,568 & 0,904 & 5,525 & 16 & $0,000^{*}$ \\
& Post-test & 45,32 & 3,34 & 0,728 & 0,664 & & & \\
\multirow{2}{*}{ Study content } & Pre-test & 9,58 & 1.34 & 0,409 & 0,996 & 8,273 & 16 & $0,000^{*}$ \\
& Post-test & 11,49 & 1,39 & 0,696 & 0,718 & & & \\
Motivation & Pre test & 112,41 & 5,17 & 0,738 & 0,647 & 0,886 & 16 & 0,195 \\
& Post test & 111,31 & 8,18 & 0,823 & 0,508 & & & \\
\multirow{2}{*}{ Expectancy } & Pre-test & 26,94 & 1,87 & 0.782 & 0,573 & 1,948 & 16 & $0,035^{* *}$ \\
& Post-test & 27,91 & 3,12 & 0,604 & 0,859 & & & \\
\hline
\end{tabular}

* significance: $\mathrm{p}<0.01$, one-tailed

** significance: $\mathrm{p}<0.05$, one-tailed

Concerning the conditions for t-tests, the $\mathrm{p}$ values of the Kolmogorov-Smirnov test in the independent (Table 3) and paired-samples (Table 4) t-tests demonstrated higher values than 0,05 for all constructs, except for 'study content' in the post-test of the independent t-test $(\mathrm{p}=0,010)$. So, except for 'study content', the samples of the measured constructs were normally distributed. Second, the values of Levene's Test for Equality of Variances in Table 3 indicate that the homogeneity of variance assumption was considered. In the case of metacognition and 'study content', the values for $F$ were large (respectively 4,221 and 4,332) and the p values were less than 0,05 (respectively 0,041 and 0,038), indicating that the variances were heterogeneous which violates a key assumption of the t-test. Therefore, for metacognition and 'study content.' the alternative way of computing the t-test was performed that accounted for heterogeneous variances and provided accurate results even when the homogeneity assumption had been violated.

Student teachers' use of metacognitive learning strategies increased significantly at the 0,01 significance level between the pre- and post-test as can be seen in the results of the independent-samples t-tests $(\mathrm{t}=4,940)$ and the paired-samples $t$-tests $(\mathrm{t}=8,418)$. The same holds for the sub constructs 'study process' ( $\mathrm{t}=4,017$ in the independent-samples $t$-tests and $t=5,525$ in the paired-samples t-tests) and 'study content' $(\mathrm{t}=5,171$ in the independent-samples t-tests and $\mathrm{t}=8,273$ in the paired-samples $\mathrm{t}$-tests) that were also enhanced at a significant level in the research period. This conclusion was in line with the moderate positive correlations between student teachers' SRL opportunities and their use of metacognitive learning strategies. So, student teachers' use of metacognitive skills rose to a higher level after increasing the SRL opportunities in the educational pre-service program.

Finally, regression analyses were performed to investigate whether student teachers' level of SRL opportunities predicted their use of metacognitive learning strategies. Table 5 displays the results of regression analyses with student teachers' SRL opportunities as the independent variable and their use of metacognitive learning strategies as the dependent variable. The results indicated once more that the degree of SRL opportunities was a significant positive predictor of the metacognition score at the 0,01 significance level $(B=0.689)$. Hence, student teachers that receive more SRL opportunities in educational programs use more metacognitive learning strategies.

Table 5: Regression analyses with SRL opportunities as the independent variable and metacognition and motivation as the dependent variables

\begin{tabular}{llll}
\hline & $t$ & $p$ & $B$ \\
\hline SRL opportunities & & & \\
(Constant) & 17,808 & 0,000 & 32,180 \\
Metacognition & 13,352 & $0,000 *$ & 0,689 \\
\hline
\end{tabular}




\begin{tabular}{llll}
\hline (Constant) & 38,977 & 0,000 & 98,144 \\
Motivation & 5,719 & $0,000^{*}$ & 0,409 \\
\hline
\end{tabular}

* significance: $\mathrm{p}<0.01$

In sum, as hypothesized, student teachers' use of metacognitive learning strategies increased significantly at the 0,01 significance level during one semester in learning environments with increased SRL opportunities. Qualitative analyses confirmed these results. In addition, qualitative analyses identified student teachers' need for more explicit metacognitive strategy instruction. These findings correspond with the recommendations of Butler (2003), Veenman et al. (2006) and Vrieling et al. (2010), indicating the necessity for primary teacher educators to explicitly model metacognitive learning strategies to their student teachers. In short, primary student teachers benefit most from explicit strategy instructions.

Qualitative analyses indicated that the level of student teachers' former education might influence student teachers' use of metacognitive skills. Riding and Al-Sanabani (1998) also state that intelligent students are more likely to develop learning strategies to supplement their leaning style than less intelligent students. Contrary to this advise, explicit training of metacognitive learning strategies was shown to to be rare in primary student teachers' classrooms. These findings are in line with the results of Kistner et al. (2010) who conclude that a great amount of strategy teaching occurs in an implicit way because teacher educators often find it difficult to serve as a role model. Teacher educators are absolutely willing to invest effort in the instruction of metacognition within their lessons, but they need the 'tools' for implementing metacognition as an integral part of their lessons and for making students aware of their metacognitive activities and the usefulness of those activities (Veenman et al., 2006).

Taking the coaching/judging construct of the SRLOQ as an example, student teachers are often required to provide feedback to peers during working on their assignments. According to Hattie and Timperly (2007), effective external feedback needs to be clear, purposeful, meaningful, and compatible with students' prior knowledge to provide logical connections. Furthermore, it needs to encourage students' active information processing, have low task complexity, relate to specific and clear goals, and provide little threat to students' feelings of self-efficacy. However, most student teachers have not been taught how to ask for and how to provide feedback. By modelling the necessary metacognitive skills, teacher educators can make their teaching more explicit and improve the transfer between theory and educational practice. During modelling, the following four steps of Schunk and Zimmerman (2007) can be used: (1) observation: learners can induce the major features of the skill from watching a model learn or perform; (2) emulation: the learner imitates performances of a model's skill with social assistance; (3) self-control: the learner independently shows a model's skill under structured conditions; and (4) self-regulation: the learner shows an adaptive use of skills across changing personal and environmental conditions.

Student teachers' motivation for learning increases significantly during one semester in learning environments with increased SRL opportunities.

The relationship between student teachers' SRL opportunities and their motivation for learning was firstly studied by means of correlation analyses (Table 2). The relationship between student teachers' SRL opportunities and their motivation for learning was shown to be significantly positive at the 0,05 significance level in the pre-test $(\mathrm{r}=0,210)$ and at the 0,01 significance level $(\mathrm{r}=0,500)$ in the post-test. So, weak to moderate positive relationships were found between 
student teachers' SRL opportunities in the educational pre-service program and their motivation for learning. In addition, all separate constructs within motivation also correlated significantly with SRL at the 0,01 significance level. In line with the expectations, the sub constructs 'Intrinsic goal avoidance', 'Extrinsic goal avoidance' and 'Test anxiety' correlated negatively with SRL and the other sub constructs ('Intrinsic goal orientation', 'Extrinsic goal orientation', 'Task value' and 'Expectancy') showed positive correlations with SRL.

Secondly, independent-samples t-tests $(t=0,659)$ and paired-samples $t$-tests $(t=0,886)$ showed no significant increase of student teachers' motivation for learning before (pre-test) and after (post-test) increasing student teachers' SRL opportunities. These results are presented in Tables 3 and 4. By contrast, the results did indicate a significant increase at the 0,05 significance level of the expectancy component within the motivational construct in both the independentsamples $t$-tests $(t=2,069)$ and the paired-samples $t$-tests $(t=1,948)$. Thus, contrary to student teachers' motivation for learning as a whole, student teachers' expectancy did increase after experiences with SRL opportunities in the educational pre-service program.

Finally, Table 5 indicates the results of regression analyses with student teachers' SRL opportunities as the independent variable and their motivation for learning as the dependent variable. The results show that the amount of SRL opportunities was a significant positive predictor of the motivational score at the 0,01 significance level $(B=0.409)$. In short, student teachers that receive more SRL opportunities in the educational program are more motivated towards learning.

Altogether, it can be concluded that student teachers' motivation for learning was enhanced during one semester in learning environments with increased SRL opportunities, but not to a significant level. Thus, the expectations of the second hypothesis could not be confirmed. However, student teachers' expectancy, a component within the motivational construct, did increase significantly in the research period. Similarly, qualitative analyses revealed that student teachers appreciated the SRL increase and felt more confident towards the transfer from theory to their own classroom practice, the assignments and the final test: 'Because we cooperated actively, we were forced to think about the subject matter of teaching, resulting in better remembrance and more confidence'.

Nevertheless, student teachers also stressed the important role of teacher educators in providing a sufficient knowledge base to avoid uncertainty. These findings corresponded with earlier findings of a theoretical study (Vrieling et al., 2010) in which primary teacher educators were advised to focus on knowledge building in the domain (subject area) by creating a gradual transfer from teacher control to student control ('scaffolding'). The qualitative findings of the present study confirmed the importance to pay attention to the conditions that can hinder or foster smooth SRL implementation in primary teacher education, namely (1) teacher 
characteristics, (2) student characteristics, (3) characteristics of learning materials and (4) characteristics of the school context and culture.

Primary teacher educators indicated to be better prepared for a gradual SRL

implementation in educational pre-service programs by applying the SRL model and according SRLOQ. Nevertheless, unlike experienced teacher educators, starting teacher educators were often so pre-occupied with their daily routine of teaching that they needed much encouragement to create real SRL opportunities. Second, although student teachers appreciated SRL, they were not always motivated to invest much time and energy in developing adequate learning skills. For example, several student teachers experienced peer feedback as an obligatory part of the assignments instead of a useful procedure to improve their work. In the case of learning materials, student teachers stressed the importance for all teacher educators to use the learning materials, for example the electronic learning environment, in the same way. Finally, a supportive school context and culture were also shown to be important aspects for a gradual SRL implementation. Primary teacher educators that perceived their schools as being more supportive were more motivated and persistent towards SRL implementation.

Qualitative findings indicated that primary student teachers appreciated collaborative tasks. By discussion, argumentation, and reflection upon the task at hand, deeper processing of the information and richer and more meaningful learning was achieved. Nevertheless, student teachers also stressed the importance for all individual members of the group to actively cooperate. When this was not the case, the advantages of the joined effort were decreased and student teachers gave privilege to working alone.

To create appropriate learning tasks, the four-component instructional design (4c-id) model (Van Merriënboer \& Kirschner, 2007) was shown to be a useful instrument for primary teacher educators. The basic claim of the $4 \mathrm{c}-\mathrm{id}$ model is that all environments for complex 
learning can be described in terms of four interrelated components: (1) learning tasks (i.e., meaningful whole tasks, based on real-life tasks that require the integrated use of knowledge, skills, and attitudes); (2) supportive information (i.e., information that helps learners to perform the problem-solving and reasoning aspects of the tasks); (3) procedural information (i.e., information that explains how to perform the routine aspects of the task); and (4) part-task practice (i.e., additional practice to develop routine aspects of the task to a very high level of automaticity).

Student teachers' motivation for learning is significantly related to student teachers' use of metacognitive learning strategies

The relationship between student teachers' use of metacognitive learning strategies and their motivation for learning was studied by means of correlation analyses (Table 2). In line with the third hypothesis, the results did show significant, although weak positive correlations at the 0,01 significance level both in the pre-test $(\mathrm{r}=0,212)$ and the post-test $(\mathrm{r}=0,338)$. In other words, student teachers' use of metacognive skills and motivation for learning seem to strengthen one another during the learning process, but only to a limited extent.

\section{Conclusions and discussion}

The present study searched for dynamics of primary student teachers' use of metacognitive learning strategies and motivation for learning in learning environments with increased SRL opportunities. The results show that student teachers' use of metacognitive learning strategies increased significantly during one semester in learning environments with increased SRL opportunities. This indicates that teacher educators can play a major role in developing student teachers' use of metacognitive learning strategies by increasing student teachers' SRL opportunities in teacher education programs. So, in line with the findings of several researchers (e.g. Riding \& Al-Sanabani, 1998), it is possible for student teachers to develop metacognitive learning strategies to cope with situations for which the individual's style is not naturally appropriate.

However, such enhancement of student teachers' use of metacognitive skills is only achieved by explicit strategy promotion to support student teachers' learning. To reach this aim, the training and fostering of student teachers' metacognitive knowledge and learning strategies should be incorporated in primary student teachers' education and training. Hattie (2009) also emphasizes the importance for teacher educators to support student teachers to develop a series of learning strategies that enables them to construct their own learning. The teaching of these strategies needs to be planned, deliberate and explicit, and part of active programs to teach specific skills and deeper understanding. During this process, the following modelling phases are 
important: observation, emulation, self-control and self-regulation. By using such modelling, teacher educators can make their teaching more explicit and improve the transfer between theory and educational practice.

In addition, the metacognitive instruction of underachieving student teachers needs to vary between student teachers suffering from an availability deficiency and student teachers with a production deficiency of metacognition (Veenman et al., 2006). The first group does not have sufficient metacognitive knowledge and skills at their disposition and needs metacognitive instruction from scratch on. The latter group has a certain level of metacognitive knowledge and skills at their disposition, but fail to use their metacognition due to task difficulty, test anxiety, lack of motivation, or their inability to see the appropriateness of metacognition in a particular situation. Their instruction can be limited to guiding metacognitive activity during task performance.

Student teachers' motivation for learning was also enhanced during one semester in learning environments with increased SRL opportunities, but this increase appeared not to be significant. One reason for the absence of motivation effects may be that the temporal interval in the present study was too brief for the effects to be detected. However, the increase of student teachers' expectancy, a component within the motivational scale, was shown to be significant. Student teachers indicated appreciation of the increased SRL opportunities in the curriculum. They felt more confident in using the provided knowledge and skills in their own classrooms and towards the assignments and the final test. Several factors might have influenced student teachers' motivation for learning in the research period. To ensure successful SRL implementation, it is important for teacher educators: (1) to create an adequate knowledge base by gradually increasing student teachers' SRL opportunities; (2) to pay attention to the conditions that can hinder or foster a gradual SRL increase; (3) to support student teachers' collaborative learning processes; and (4) to develop appropriate learning tasks. These factors are explained in the coming sections.

Student teachers stressed the importance for teacher educators to provide an adequate knowledge base to avoid uncertainty. According to student teachers, teacher educators are experts in the relevant subject domain and it is their task to make this domain more accessible to student teachers. For example, student teachers like to know the criteria for judging their work in advance. Therefore, in line with earlier findings of a theoretical study (Vrieling et al., 2010), primary teacher educators are advised to focus on knowledge building in the domain by organizing a gradual development from teacher control to student control in the educational preservice program. The SRLOQ (Vrieling et al., 2011b) can be applied as a diagnostic instrument during this implementation process. Teacher educators can be trained in using the SRL model (Vrieling et al., 2010) and according SRLOQ to be better prepared for SRL implementation in teacher education programs.

In an optimally scaffolded instruction, teacher educators gradually decrease assistance when the student teachers are able to perform more independently (Salonen, Vauras, \& Efklides, 2005). However, Salonen et al. (2005) report about 'scaffold mismatches' in their research, meaning that sometimes mismatches occur between the learners' needs and the guidance of the teacher. In their study of metacognition as a socio-cognitive phenomenon was shown that students' judgments of their own metacognitive experiences are more closely related to their performance than the judgments of peers or teachers. Peers' and teachers' judgments are presumably driven by normative criteria of performance or by theory- or belief-driven views about ability.

Thus, if we are to gradually increase student teachers' SRL opportunities in educational 
pre-service programs, it is essential for teacher educators to demonstrate flexibility (the ability to accommodate flexibly to individual characteristics and needs), sensitivity (the ability to sense and to respond to 'online' changes in each particular learner's cognitions, motivations, affects, and moods); and responsiveness (the ability to respond systematically, coherently, and as immediately as possible to learners' cognitive efforts, and motivational, affective, and social responses). To establish and maintain a dynamic match between student teachers and teacher educators, the professional development of teacher educators needs to differentiate between experienced and starting teacher educators.

Besides an adequate preparation of teacher educators to obtain successful SRL implementation, student teachers must be aware of the importance of SRL for their academic success. Also, in line with the findings of Sim and Hew (2010) in higher education settings, reflective learning in (electronic) learning environments requires clear instructions and sufficient time to be appreciated and adopted in student teachers' learning. Finally, it is important for policy makers to embed SRL as a central issue within educational pre-service programs.

To avoid problematic collaboration circumstances that can decrease student teachers' motivation for learning, teacher educators must pay attention to positive interdependence in the group, clear instructions on how to co-operate and appropriate feedback on the co-operating process (Bolhuis \& Voeten, 2001). In addition, the transaction costs (communication and coordination within the group) should be kept to a minimum to ensure positive interdependence (Kirschner, Paas, \& Kirschner, 2009).

Considering the learning task, the 4c-id model (Van Merriënboer \& Kirschner, 2007) can be an appropriate model for primary teacher education. Student teachers start with relative simple, but realistic situations that contain all essential aspects of the complex task. Then, 
student teachers gradually receive more complex assignments, characteristic for their

professional situation. In this way, a better transfer between theory and practice can be achieved.

In line with earlier theoretical findings (e.g. Berger \& Karabenick, 2011), the relationship between student teachers' use of metacognitive learning strategies and their motivation for learning, was shown to be positively significant, but weak, in the present study. Thus, primary student teachers' use of metacognive skills and motivation for learning seem to strengthen one another during the learning process, but only in a minor way. Therefore, motivation and cognition must be conceived as interacting constructs in research regarding SRL. Together, these components are assumed to influence students' involvement with their learning and, consequently, academic performance (Eccles \& Wigfield, 2002; Pintrich, 2000, 2004).

A first limitation of the present study is that no control group was assessed. The point of reference used was the starting situation of student teachers' SRL opportunities. Other experiences by teacher educators and student teachers between the pre- and post-test might have influenced the results of the study. Second, all participating teacher educators volunteered to cooperate and can therefore not be regarded as a fully representative sample of the population. To broaden the perspective on the relationships between SRL, motivation for learning and the use of metacognitive learning strategies, future research would benefit from applying (on-line) measurement methods to obtain behavioral measures during task performance over a longer period of time. For example, instruments like 'Regulation of Motivation' (Wolters, 2003) can measure the motivational construct to evaluate changes in motivation. In this way, motivation is assessed as a process or an event instead of a product or an aptitude (Winne \& Perry, 2000). In the same matter, metacognitive feelings, judgments/estimates, and thoughts students are aware of during task performance can be assessed during learning (Efklides, 2006). Future research can also aim at the measurement of student teachers' study results after increasing their SRL opportunities in similar educational pre-service settings. Finally, it would be interesting to search for possible reciprocal effects between motivation and metacognition in primary teacher education. 
In general, this study revealed that the level of SRL opportunities in pre-service teacher learning environments is a moderate predictor of primary student teachers' use of metacognitive learning strategies and motivation for learning, both important constructs for their academic career.

\section{Acknowledgements:}

This research was supported by the Zestor foundation under project number PRO634-B-E.

Appendix A. Questions semi-structured interviews
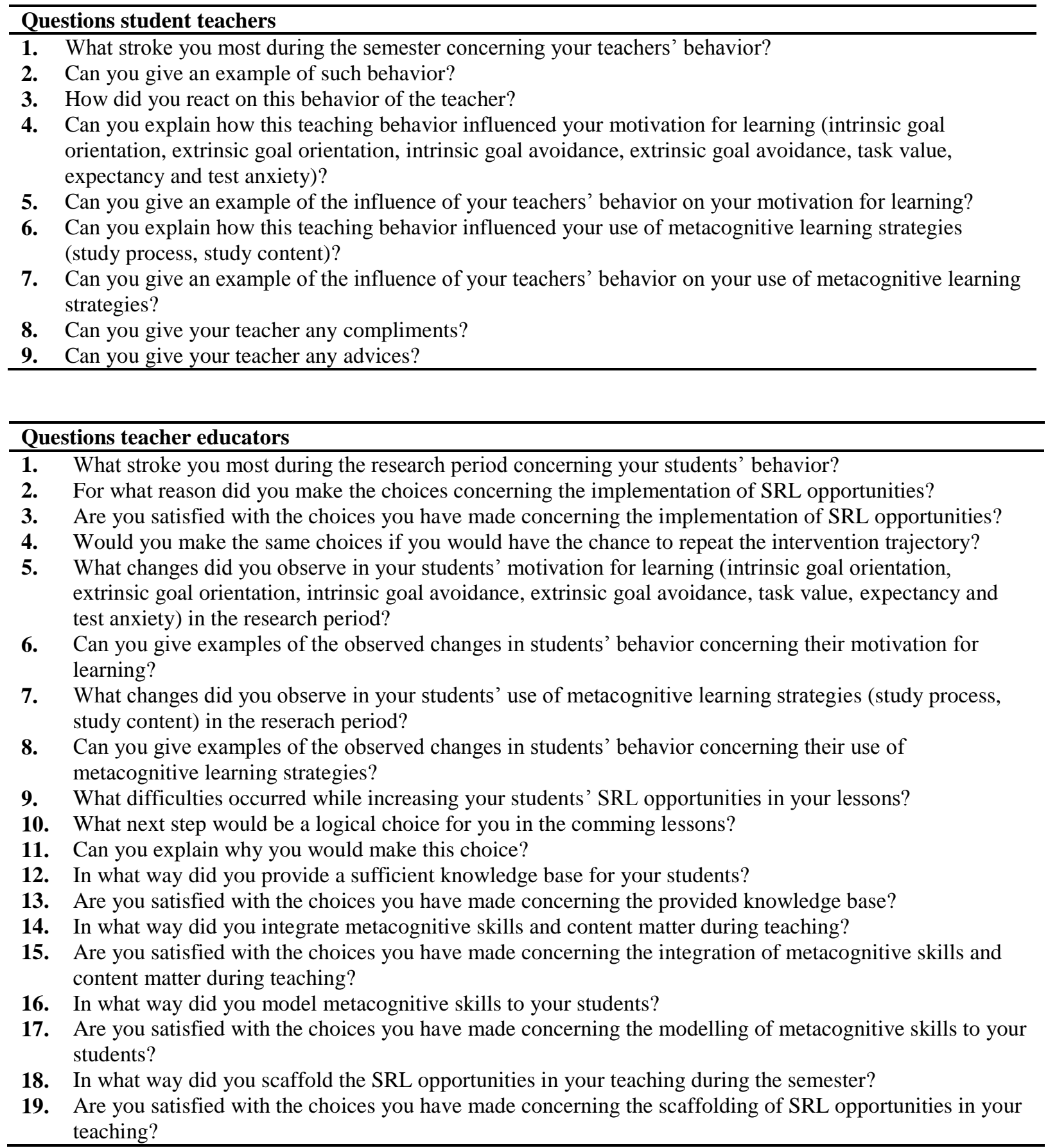
20. In what way did conditional factors factors (teacher characteristics, student characteristics, characteristics of learning materials and characteristics of the school context and culture) hinder or foster SRL development in your teaching?

21. Are you satisfied with the way you delt with the conditional factors that hindered or fostered SRL development in your teaching?

22. Can you give suggestions to improve the intervention trajectory?

\section{References}

Berger, J-L., \& Karabenick, S.A. (2011). Motivation and students' use of learning strategies: Evidence of unidirectional effects in mathematics classrooms. Learning and Instruction, $21,416-428$.

Blom, S., \& Severiens, S. (2008). Engagement in self-regulated deep learning of successful immigrant and non-immigrant students in inner city schools. European Journal of Psychology of Education, 23, 41-58.

Blom, S., Severiens, S., Broekkamp, H, \& Hoek, D. (2005). Eindrapport project zelfstandig leren van allochtone en autochtone leerlingen in het studiehuis [Final report of the independent learning project of allochthonous and autochthonal students in independent study centers], 1999-2004. Amsterdam: Instituut voor de lerarenopleidingen, Universiteit van Amsterdam. Adviespunt tweede fase, Ministerie van OC\&W.

Bolhuis, S., \& Voeten, M.J.M. (2001). Toward self-directed learning in secondary schools: What do teachers do? Teaching and Teacher Education, 17, 837-855.

Butler, D.L. (2002). Individualizing instruction in self-regulated learning. Theory into Practice, 41, 81-92.

Butler, D.L. (2003). Structuring instruction to promote self-regulated learning by adolescents and adults with learning disabilities. Exceptionality, 11, 39-60.

Bruinsma, M. (2004). Motivation, cognitive processing and achievement in higher education. Learning and Instruction, 14, 549-568.

Eccles, J.S., \& Wigfield, A. (2002). Motivational beliefs, values, and goals. Annual Review of Psychology, 53, 109-132.

Efklides, A. (2006). Metacognitive experiences: The missing link in the self-regulated learning process. Educational Psychology Review, 18, 287-291.

Elliot, A.J., \& McGregor, H.A. (2001). A 2x2 Achievement goal framework. Journal of Personality and social Psychology, 80, 501-519.

Hattie, J. (2009) Visible learning: A synthesis of over 800 meta-analyses relating to achievement. Routledge: London and new York.

Hattie, J., \& Timperly, H. (2007). The power of feedback. Review of Educational Research, 77, 81-112.

Järvelä, S., Järvenoja, H.B \& Veermans, M. (2008). Understanding the dynamics of motivation in socially shared learning. International Journal of Educational Research, 47, 122-135. 
Kirschner, F., Paas, F., \& Kirschner, P.A. (2009). A cognitive load approach to collaborative learning: United brains for complex tasks. Educational Psychological Review, 21, 31

Kistner, S., Rakoczy, K., Otto, B., Dignath-van Ewijk, Ch., Büttner, G., \& Klieme, E. (2010). Promotion of self-regulated learning in classrooms: Investigating frequency, quality, and consequences for student performance. Metacognition and learning, 5, 157-172.

Korthagen, F., Klaassen, C., \& Russell, T. (2000) New learning in teacher education. In P.R-J. Simons, J. van der Linden, \& T, Duffy [eds.], New learning (pp. 243-259). Dordrecht: Kluwer Academic Publishers.

Kremer-Hayon, L., \& Tillema, H.H. (1999). Self-regulated learning in the context of teacher education. Teaching and Teacher Education, 15, 507-522.

Lunenberg, M., \& Korthagen, F.A.J. (2003). Teacher educators and student-directed learning. Teaching and Teacher education, 19, 29-44.

Miles, M.B., \& Huberman, A.M. (1994). Qualitative data analysis: An expanded sourcebook $\left(2^{\text {nd }}\right.$ ed.) London: SAGE Publications.

Muis, K.R.. \& Franco, G.M. (2010). Epistemic profiles and metacognition: Support for the consistency hypothesis. Metacognition and learning, 5, 27-45.

Nota, L., Soresi, S., \& Zimmerman, B.J. (2004). Self-regulation and academic achievement and resilience: A longitudinal study. International Journal of Educational Research, 41, 198-215.

Pintrich. P.R. (2000). The role of goal orientation in self-regulated learning. In M. Boekaerts, P.R. Pintrich, \& M. Zeidner (eds.), Handbook of self-regulation (pp. 451-502). San Diego, CA: Academic Press.

Pintrich, P.R. (2004). A conceptual framework for assessing motivation and self-regulated learning in college students. Educational Psychology Review, 16, 385-407.

Pintrich, P.R., \& De Groot, E.V. (1990). Motivational and self-regulated learning components of classroom academic performance. Journal of Educational Psychology, 82, 13-40.

Pintrich, P.R., Smith, D., Garcia, T., \& McKeachie, W.J. (1991). A manual for the use of the Motivated Strategies for learning Questionnaire (MSLQ). Ann Arbor: University of Michigan, School of Education.

Riding, R.J., \& Al-Sanabani, S.A. (1998). The effect of cognitive style, age, gender and structure on the recall of prose passages. International Journal of Educational Research, 29, 173185.

Salonen, P., Vauras, M., \& Efklides, A. (2005). Social interaction: What can it tell us about metacognition and coregulation in Learning? European Psychologist, 10, 199-208.

Schunk (2005). The educational legacy of Paul R. Pintrich. Educational Psychologist, 40, 8594.

Schunk, D.H., \& Ertmer, P.A. (2000). Self-regulation and academic learning. In M. Boekaerts, P.R. Pintrich, \& M. Zeidner (eds.), Handbook of self-regulation (pp. 631-649). San Diego, CA: Academic Press.

Schunk, D.H., \& Zimmerman, B. (2007). Influencing children's self-efficacy and self-regulation of reading and writing through modelling. Reading and Writing Quarterly, 23, 7-25.

Sim, J.W.S., \& Hew, K.F. (2010). The use of weblogs in higher education settings: A review of empirical research. Educational Research Review, 5, 151-163. 
Sundre, D.L., \& Kitsantas, A. (2004). An exploration of the psychology of the examinee: Can examinee self-regulation and test-taking motivation predict consequential and nonconsequential test performance? Contemporary Educational Psychology, 29, 6-26.

Valle, A., Cabanach, R.G., Núñez, J.C., González-Pienda, J., Rodríguez, S., \& Piñeiro, I. (2003). Cognitive, motivational, and volitional dimensions of learning. Research in Higher Education, 44, 557-580.

VanderStoep, S.W., Pintrich, P.R., \& Fagerlin, A. (1996). Disciplinary differences in selfregulated learning in college students. Contemporary Educational Psychology, 21, 345-362.

Van Merriënboer, J. J. G., \& Kirschner, P. A. (2007). Ten steps to complex learning. Mahwah, NJ: Erlbaum. .

Veenman, M.V.J., Van Hout-Wolters, B.H.A.M., \& Afflerbach, P. (2006). Metacognition and learning: Conceptual and methodological considerations. Metacognition and learning, 1, 3-14.

Vermunt, J.D.H.M., \& Van Rijswijk, F.A.W.M. (1987). Inventaris Leerstijlen voor het hoger onderwijs [Inventory of Learning Styles for higher education]. Tilburg: Katholieke Universiteit Brabant, Sectie Onderwijspsychologie. Heerlen: Open Universiteit, afdeling Onderzoek en Evaluatie.

Vermunt, J.D., \& Verloop, N. (1999). Congruence and friction between learning and teaching. Learning and Instruction, 9, 257-280.

Vrieling, E.M., Bastiaens, T.J., \& Stijnen, S. (2010). Process-oriented design principles for promoting self-regulated learning in primary teacher education. International Journal of Educational Research, 49, 141-150.

Vrieling, E.M., Bastiaens, T.J., \& Stijnen, S. (2011a). Effects of increased self-regulated learning opportunities on student teachers' motivation and use of metacognitive skills. Manuscript submitted for publication.

Vrieling, E.M., Bastiaens, T.J., \& Stijnen, S. (2011b). The 'Self-Regulated Learning Opportunities Questionnaire': A diagnostic instrument for primary teacher educators. Manuscript submitted for publication.

Winne, P.H., \& Perry, N.E. (2000). Measuring self-regulated learning. In M. Boekaerts, P.R. Pintrich, \& M. Zeidner (eds.), Handbook of self-regulation (pp. 531-566). San Diego, CA: Academic Press.

Wolters, C.A. (2003). Regulation of motivation: evaluating an underemphasized aspect of selfregulated learning. Educational Psychologist, 38, 189-205.

Zimmerman, B.J. (1999). Commentary: Toward a cyclically interactive view of self-regulated learning. International Journal of Educational Research, 31, 545-551.

Zimmerman, B. J. (2000). Attaining self-regulation: A social cognitive perspective. In M. Boekaerts, P. R. Pintrich, \& M. Zeidner (Eds.), Handbook of self-regulation (pp. 13-39). San Diego, CA: Academic.

Zimmerman, B.J., \& Pons, M.M. (1988). Construct validation of a strategy model of student selfregulated learning. Journal of Educational Psychology, 80, 284-290.

Zimmerman, B.J., \& Schunk, D.H. (2001). Reflections on theories of self-regulated learning and academic achievement. In B. J. Zimmerman, \& D. H. Schunk [eds.], Self-regulated 
Effects of SRL 23

learning and academic achievement: Theoretical perspectives (pp. 289-307). Mahwah, NJ: Lawrence Erlbaum. 